\title{
Prevalence of fruite (kiwi) allergy in health worker with latex hypersensitivity
}

\author{
Sayyed Hesamedin Nabavizadeh ${ }^{1 *}$, Shiva Yazdanpanah ${ }^{2}$ \\ From Food Allergy and Anaphylaxis Meeting 2011 \\ Venice, Italy. 17-19 February 2011
}

\begin{abstract}
Allrgic reaction to natural rubber latex have increased during past 10 years especially among health worker and patients with high exposure to latex allergen. Latex allergy is associsted with clinical or serological cross reactivity to plant derived food allergen especially tropical fruit for example avocado bannana chestnut kiwi papaya potato and peaches. In this study on health worker among 580 participants 104(17.9\%) who were positive to latex skin prick test.Of 464 patients with negative skin prick test to latex are have 12 patiets with positive skin prick test to kiwi and in 197 patiens with positive skin prick test to latex 7 patients had positive skin prick test to kiwi $(\mathrm{p}<0.05)$. In this study difference of sensivity to banana and potato in both groups were not significant according to this study kiwi hypersensivity is important problem among health worker with sensivity to latex.
\end{abstract}

\section{Key words}

latex Allergy -kiwi - skin prick test

\section{Author details \\ ${ }^{1}$ Yasouj University of Medicine, Allergy, Yasouj, Islamic Republic of Iran. \\ ${ }^{2}$ Valfajr Health Center, Health Center, Shiraz, Islamic Republic of Iran.}

Published: 12 August 2011

doi:10.1186/2045-7022-1-S1-P33

Cite this article as: Nabavizadeh and Yazdanpanah: Prevalence of fruite

(kiwi) allergy in health worker with latex hypersensitivity. Clinical and

Translational Allergy 2011 1(Suppl 1):P33.

${ }^{1}$ Yasouj University of Medicine, Allergy, Yasouj, Islamic Republic of Iran

Full list of author information is available at the end of the article

Submit your next manuscript to BioMed Central and take full advantage of:

- Convenient online submission

- Thorough peer review

- No space constraints or color figure charges

- Immediate publication on acceptance

- Inclusion in PubMed, CAS, Scopus and Google Scholar

- Research which is freely available for redistribution
C BioMed Central 